\section{Host Range of a California Sting Nematode Population}

\author{
S. Bekal ${ }^{1}$ and J.O. Becker ${ }^{2}$ \\ Department of Nematology, University of California, Riverside, CA 92521
}

Additional index words. Belonolaimus longicaudatus, physiological races

\begin{abstract}
Recently, sting nematodes were discovered associated with dying turfgrass in several golf courses in Coachella Valley, Calif. Based on their morphology and internal transcribed spacer (ITS) rDNA restriction pattern, the pests were identified as Belonolaimus longicaudatus Rau. This study was undertaken to determine the host status of 60 different plant species and cultivars for a California population of $B$. longicaudatus. The host range tests were conducted under greenhouse conditions at $25 \pm 2{ }^{\circ} \mathrm{C}$ and ambient light. At the second-leaf stage, each pot was infested with $55 \pm 12$ adults or fourth-stage juveniles per $150 \mathrm{~g}$ of blow sand. The population densities determined after 7 weeks of incubation qualified $>\mathbf{8 0 \%}$ of the plants tested as good hosts with a reproduction factor $(\mathrm{Rf}=\mathrm{Pf} / \mathrm{Pi})$ $>4$. The majority of those were grasses, although reproduction was best on Gossypium hirsutum $\mathrm{L}$. with $\mathrm{Rf}=$ 58.6. While Capsicum annum $\mathrm{L}$., Medicago sativa $\mathrm{L}$., Arachis hypogaea L., Euphorbia glyptosperma Engelm., Cucumis sativus L., and Daucus carota L. were less suitable host plants with $\mathrm{Rf}<4$, only Abelmoschus esculentus (L.) Moench, Citrullus lanatus Thunb., and Nicotiana tabacum $\mathrm{L}$. were nonhosts among the tested species. This sting nematode population had a high reproductive fitness on a majority of species tested and must be considered a major threat for most agricultural and horticultural crops grown in sandy soils.
\end{abstract}

Nematodes of the genus Belonolaimus Steiner include five ectoparasitic species endemic to sandy soils of the southern and midwestern United States (Smart and Nguyen, 1991). They are polyphagus feeders with a wide host range and potentially damage many economically important crops in soils with a minimum of $80 \%$ sand (Robbins and Barker, 1974). Belonolaimus longicaudatus Rau has been described as the most damaging species of the genus (Duncan et al., 1996; Perry and Rhoades, 1982; Smart and Nguyen, 1991; Todd, 1989). Host lists of several sting nematode populations were published previously (Abu-Gharbieh and Perry, 1970; Esser, 1976; Graham and Holdeman, 1953). However, $B$. longicaudatus and B. gracilis Steiner often have been confused (Rau, 1958). Differences in host reactions and fitness were reported for some B. longicaudatus populations of Florida, North Carolina, and Georgia (Abu-Gharbieh and Perry, 1970; Robbins and Barker, 1973), which suggested the occurrence of several physiological races within this species.

Recently, sting nematodes were discov-

Received for publication 23 Aug. 1999 Accepted for publication 10 Apr. 2000. This project was supported by funds from the Univ. of California IPM program. We thank V. Gibeault and R. Autio for providing most of the grass seeds, and C.M. Hutchinson and V. Gibeault for reviewing the manuscript. The cost of publishing this paper was defrayed in part by the payment of page charges. Under postal regulations, this paper therefore must be hereby marked advertisement solely to indicate this fact.

${ }^{1}$ Visiting Postdoctoral Researcher.

${ }^{2}$ Associate Cooperative Extension Specialist and Associate Nematologist; to whom reprint requests should be addressed. E-mail: ole.becker@ucr.edu ered associated with dying turfgrass in several golf courses in Coachella Valley, Calif. (Mundo-Ocampo et al., 1994). Based on its morphology (Mundo-Ocampo et al., 1994) and its rDNA internal transcribed spacer region (Cherry et al., 1997), the pest was identified as B. longicaudatus. This study was undertaken to determine the host status of 60 different plant species and cultivars for the Coachella population of $B$. longicaudatus. The results provide information needed to anticipate the potential problems with this nematode for plant industries in the southwestern United States.

\section{Materials and Methods}

The population of sting nematodes tested was collected from an infested green of a private golf course at Rancho Mirage, Calif. The nematode population was maintained on bermudagrass [Cynodon dactylon (L.) Pers.] in greenhouse pot cultures. California regulatory restrictions, which classified the sting nematode at the time of these experiments as an exotic pest, limited research on this nematode to quarantine facilities approved by the U.S. Dept. of Agriculture and the California Dept. for Food and Agriculture. Consequently, all laboratory and greenhouse research was conducted in the Dept. of Nematology Quarantine Facilities, Univ. of California, Riverside. Nematode inoculum was extracted from the greenhouse cultures using a modified sieving and centrifugal-flotation method (Jenkins, 1964). Nematodes were collected on a $45-\mu \mathrm{m}$ opening sieve. After each extraction, nematodes were centrifuged at $400 g_{\mathrm{n}}$ for $5 \mathrm{~min}$. The upper $2 \mathrm{~cm}$ of surface water in each $50-\mathrm{mL}$ tube was air aspirated, and the supernatant was saved in a beaker. The pellet was mixed with
$1.5 \mathrm{~m}$ sucrose and recentrifuged at $350 \mathrm{~g}_{\mathrm{n}}$ for 30 to $40 \mathrm{~s}$. The supernatant was collected and combined with the supernatant from the first centrifugation. Nematodes were collected by pouring the supernatant through a $25-\mu \mathrm{m}$ pore sieve. Most of the $\mathrm{J} 2$ and $\mathrm{J} 3$ were eliminated with successive additional sieving by passing nematode suspensions through a $90-\mu \mathrm{m}$ pore sieve and decanting for 5 to $10 \mathrm{~min}$. The nematode suspension was counted under low magnification. Sixty different plant species and cultivars derived from 14 different botanical families were tested. Seeds were planted in 7 -cm-diameter pots filled with $150 \mathrm{~g}$ of steampasteurized blow sand and maintained in the greenhouse at $25 \pm 2{ }^{\circ} \mathrm{C}$ in ambient light. The large number of plant species and greenhouse space limitations required that the host range tests be conducted in consecutive trials. Each trial included 'Arizona common' bermudagrass (C. dactylon) as a control. Each treatment consisted of four replicates. Two additional pots without nematodes were used as controls for each treatment. The treatments were arranged in a randomized complete block. At the second-leaf stage, each pot was infested with a freshly extracted nematode suspension consisting of $55 \pm 12$ adults or J4 nematodes (female : male ratio $\approx 3: 2$ ). The plants received $20 \mathrm{~mL}$ fertilizer solution ( $10 \mathrm{~g}$ of Miracle Gro per $4 \mathrm{~L}$ water, 15N-30P-15K, Scotts Miracle Gro Products, Port Washington, N.Y.) each week. Nematode population density was determined after 7 weeks by extracting the contents of each pot using the modified centrifugal-flotation method described above. After each extraction, roots were washed and gently dried with absorbent paper. Root fresh weight was taken from both inoculated and noninoculated plants. A reproductive factor (Rf) for each plant-nematode combination was calculated by dividing the final sting nematode population by the initial inoculum (Seinhorst, 1967)

All data were subjected to analysis of variance. Means comparison of the Rf was performed on transformed $\log (\mathrm{x}+1)$ data with the Fisher's protected least significance difference (LSD) test. Means comparison of weights of the infested and healthy roots was accomplished with the F test. The trial was repeated for plants that classified as nonhost plants.

\section{Results and Discussion}

The tests demonstrated both the nematode's wide host range and its high reproductive fitness. On $>80 \%$ of the plant species tested, the sting nematode population had a high multiplication rate $(\mathrm{Rf}>5)$ despite a fairly short test period (Table 1). About $10 \%$ of the plants tested were poorly suited for the nematode population $(\mathrm{Rf}<5)$. The population declined only under Abelmoschus esculentus, Nicotiana tabacum, and Citrullus lanatus. Furthermore, nojuveniles were recovered from those plants. Adults of the sting nematode recovered from pots with A. esculentus and $N$. tabacum appeared particularly frail and malnourished. Hence, those plants were catego- 
Table 1 . Host reactions to a California population of the sting nematode.

\begin{tabular}{|c|c|c|c|}
\hline $\begin{array}{l}\text { Common name and cultivar } \\
\text { and designation }\end{array}$ & Scientific name & Family & $\mathrm{Rf}^{\mathrm{z}}$ \\
\hline Okra 'Clemson 80' & Abelmoschus esculentus (L.) Moench & Malvaceae & $\begin{array}{l}0.4 \pm 0.06 \mathrm{a}^{\mathrm{y}} \\
0.6 \pm 0.2^{\mathrm{x}}\end{array}$ \\
\hline Tobacco 'Xanthi' & Nicotiana tabacum L. & Solanaceae & $\begin{array}{l}0.5 \pm 0.08 \mathrm{a} \\
0.2 \pm 0.06^{\mathrm{x}}\end{array}$ \\
\hline Watermelon 'Solid Gold' & Citrullus lanatus Thunb. & Cucurbitaceae Juss. & $\begin{array}{l}0.7 \pm 0.2 \mathrm{a} \\
0.9 \pm 0.1^{\mathrm{x}}\end{array}$ \\
\hline Ridgeseed spurge & Euphorbia glyptosperma Engelm. & Euphorbiaceae Juss. & $2.2 \pm 0.9 \mathrm{~b}$ \\
\hline Squash 'Prelude' & Cucurbita maxima $\mathrm{L}$. & Cucurbitaceae Juss. & $2.3 \pm 0.7 \mathrm{bc}$ \\
\hline Cucumber 'Kidma' & Cucumis sativus L. & Cucurbitaceae Juss. & $2.6 \pm 0.9 \mathrm{bc}$ \\
\hline Carrot 'Goldmine' & Daucus carota $\mathrm{L}$. & Apiaceae & $3.1 \pm 0.8 \mathrm{bc}$ \\
\hline Peanut 'GFA Spanish' & Arachis hypogaea $\mathrm{L}$. & Fabaceae & $3.6 \pm 0.6 \mathrm{bc}$ \\
\hline Alfalfa 'CUF 10' & Medicago sativa $\mathrm{L}$. & Fabaceae & $3.7 \pm 0.7 \mathrm{bc}$ \\
\hline Pepper 'California Wonder' & Capsicum аппиит $\mathrm{L}$. & Solanaceae & $3.8 \pm 1.3 \mathrm{bc}$ \\
\hline Wheat 'Yecora Rojo' & Triticum aestivum $\mathrm{L}$. & Poaceae & $5.3 \pm 1.3 \mathrm{~cd}$ \\
\hline Turnip 'Seven Top' & Brassica rapa $\mathrm{L}$. & Brassicaceae & $6.1 \pm 2 \mathrm{~cd}$ \\
\hline Prostrate pigweed & Amaranthus blitoides (S.) Watson. & Amaranthaceae Juss. & $6.3 \pm 1.6 \mathrm{~cd}$ \\
\hline Lupine 'Russell's Hybrid' & Lupinus hirsutus L. & Fabaceae & $6.8 \pm 1.3 \mathrm{~cd}$ \\
\hline London rocket & Sisymbrium irio L. & Brassicaceae & $8.5 \pm 1.8 \mathrm{~cd}$ \\
\hline Zoysiagrass 'Emerald' & Zoysia sp. (L.) Merr. & Poaceae & $9.2 \pm 1.5 \mathrm{~cd}$ \\
\hline Shepherdspurse & Capsella bursa-pastoris (L.) Medic. & Brassicaceae & $10.0 \pm 2.3 \mathrm{de}$ \\
\hline Lambsquarters & Chenopodium album $\mathrm{L}$. & Chenopodiaceae Venten. & $10.8 \pm 2.1 \mathrm{de}$ \\
\hline Lettuce 'Yuma' & Lactuca sativa $\mathrm{L}$. & Asteraceae Dumort. & $11.4 \pm 3.2 \mathrm{de}$ \\
\hline Soybean 'Norchief' & Glycine $\max (\mathrm{L}$.$) Merrill$ & Fabaceae & $11.5 \pm 3.4 \mathrm{de}$ \\
\hline Purple nutsedge & Cyperus rotundus $\mathrm{L}$. & Cyperaceae & $12.2 \pm 2.7 \mathrm{de}$ \\
\hline Potato 'California White' & Solanum tuberosum $\mathrm{L}$. & Solanaceae & $12.4 \pm 6.1 \mathrm{de}$ \\
\hline Cantaloupe 'Sierra Gold' & Cucumis melo $\mathrm{L}$. & Cucurbitaceae Juss. & $12.7 \pm 4.1 \mathrm{de}$ \\
\hline Annual bluegrass & Poa anпua $\mathrm{L}$ & Poaceae & $13.1 \pm 5.2 \mathrm{de}$ \\
\hline Tomato 'Pixie' & Lycopersicon esculentum Mill. & Solanaceae & $13.6 \pm 4.5 \mathrm{de}$ \\
\hline Radish 'Cherry Belle' & Raphanus sativus $\mathrm{L}$ & Brassicaceae & $14.3 \pm 5.0 \mathrm{de}$ \\
\hline Onion 'Southport White Globe' & Allium сера $\mathrm{L}$. & Liliaceae & $14.5 \pm 3.3 \mathrm{de}$ \\
\hline Barley '603' & Hordeum vulgare $\mathrm{L}$. & Poaceae & $15.8 \pm 4.2 \mathrm{de}$ \\
\hline Zoysiagrass 'De Anza' & Zoysia sp. (L.) Merr. & Poaceae & $16.1 \pm 3.7$ ef \\
\hline Yellow nutsedge & Cyperus esculentus L. & Cyperaceae & $16.5 \pm 4.5 \mathrm{ef}$ \\
\hline Wild mustard & Brassica kaber (D.C.) L.C. Wheeler & Brassicaceae & $17.2 \pm 6.1 \mathrm{ef}$ \\
\hline Spinach 'Bloomsdale' & Spinacia oleracea L. & Chenopodiaceae Venten. & $18.4 \pm 4.3$ ef \\
\hline Purslane & Portulaca oleracea L. & Portulacaceae Juss. & $19.2 \pm 4.1 \mathrm{ef}$ \\
\hline Soybean 'Horosay' & Glycine max (L.) Merrill & Fabaceae & $19.2 \pm 4.8$ ef \\
\hline Pearl millet & Pennisetum glaucum L. & Poaceae & $20.6 \pm 4.5$ ef \\
\hline Bermudagrass 'Sahara' & Cynodon dactylon (L.) Pers. & Poaceae & $20.7 \pm 5.1 \mathrm{ef}$ \\
\hline Zoysiagrass 'Victoria' & Zoysia sp. (L.) Merr. & Poaceae & $20.9 \pm 4.7$ ef \\
\hline Cowpea 'Iron Clay' & Vigna unguiculata (L.) Walp. & Fabaceae & $21.2 \pm 6.2 \mathrm{ef}$ \\
\hline Sorghum 'Red Top' & Sorghum bicolor (L.) Moench & Poaceae & $22.0 \pm 5.8 \mathrm{ef}$ \\
\hline Dallisgrass & Paspalum dilatatum Poir. & Poaceae & $22.5 \pm 4.3 \mathrm{ef}$ \\
\hline Tall fescue 'Short Top' & Festuca arundinacea Schreb. & Poaceae & $23.8 \pm 5.2 \mathrm{ef}$ \\
\hline Kentucky bluegrass & Poa pratensis $\mathrm{L}$. & Poaceae & $25.0 \pm 6.0 \mathrm{fg}$ \\
\hline Bush bean 'Blue Lake Bush' & Phaseolus vulgaris L. & Fabaceae & $26.8 \pm 4.3 \mathrm{fg}$ \\
\hline Bermudagrass 'Arizona common' & Cynodon dactylon (L.) Pers. & Poaceae & $27.9 \pm 3.9 \mathrm{fg}$ \\
\hline Cowpea 'Pinkeye Purple Hull' & Vigna unguiculata (L.) Walp. & Fabaceae & $30.0 \pm 5.6 \mathrm{fg}$ \\
\hline Corn 'Golden Jubilee' & Zea mays $\mathrm{L}$. & Poaceae & $30.6 \pm 8.1 \mathrm{fg}$ \\
\hline Black nightshade & Solanum nigrum $\mathrm{L}$. & Solanaceae & $32.7 \pm 6.5 \mathrm{fg}$ \\
\hline Creeping bentgrass & Agrostis stolonifera L. & Poaceae & $33.0 \pm 4.4 \mathrm{fg}$ \\
\hline Eggplant 'Bambino' & Solanum melongena L. & Solanaceae & $33.5 \pm 3.6 \mathrm{fg}$ \\
\hline Sudangrass & Sorghum sudanense Staph. & Poaceae & $33.9 \pm 4.8 \mathrm{fg}$ \\
\hline Italian ryegrass & Lolium multiflorum Lam. & Poaceae & $36.1 \pm 5.9 \mathrm{fg}$ \\
\hline Perennial ryegrass & Lolium perenne $\mathrm{L}$. & Poaceae & $43.1 \pm 6.3 \mathrm{fg}$ \\
\hline Lima bean 'Henderson Bush' & Phaseolus limensis Macfad. & Fabaceae & $44.6 \pm 8.1 \mathrm{fg}$ \\
\hline Tall fescue 'Marathon' & Festuca arundinacea Schreb. & Poaceae & $48.5 \pm 9.3 \mathrm{f}-\mathrm{h}$ \\
\hline Smutgrass & Sporobolus indicus (L.) R. Br. & Poaceae & $49.7 \pm 11 \mathrm{f}-\mathrm{h}$ \\
\hline Crabgrass & Digitaria sanguinalis (L.) Scop. & Poaceae & $50.0 \pm 7.2 \mathrm{f}-\mathrm{h}$ \\
\hline Western wheatgrass & Elymus smithii (Rybd.) Gould & Poaceae & $50.1 \pm 6.5 \mathrm{f}-\mathrm{h}$ \\
\hline Sorghum 'Sanita' & Sorghum bicolor (L.) Moench & Poaceae & $52.3 \pm 10.3 \mathrm{f}-\mathrm{h}$ \\
\hline Winter rye & Secale cereale $\mathrm{L}$. & Poaceae & $57.0 \pm 12 \mathrm{gh}$ \\
\hline Cotton 'Maxxa' & Gossypium hirsutum L. & Malvaceae & $58.6 \pm 9.3 \mathrm{gh}$ \\
\hline
\end{tabular}

${ }^{\mathrm{z}} \mathrm{Rf}$ values (final population/initial population; $\mathrm{Rf}<1=$ nonhosts; $\mathrm{Rf} 1-4=$ poor hosts; $\mathrm{Rf}>4=$ good hosts.

'Mean separation by Fisher's protected LSD of transformed $\log (\mathrm{Rf}+1)$ at $P \leq 0.05$.

${ }^{x} \mathrm{Rf}$ values of the repeated experiment with nonhost plants. 
rized as nonhosts with $\mathrm{Rf}<1$ (Table 1). Cynodon dactylon 'Arizona common' was a suitable control for the two complete sets of experiments, with no significant differences in the $\mathrm{Rf}$ for this host between the two trials $(P>0.05)$. All of the Poacaea, which constituted $50 \%$ of the experimental plants, were good hosts. Two species in the Cucurbitaceae (Cucurbita maxima $\mathrm{L}$. and Cucumis sativus $\mathrm{L}$.) were poor hosts and one was a nonhost (Citrullus lanatus). The Solanaceae included representatives from both nonhosts, such as N. tabacum, and good hosts, such as Solanum nigrum L., S. melongena L., Solanum tuberosum L., and Lycopersicon esculentum Mill.

Citrullus lanatus, A. esculentus, and $N$. tabacum were reported as nonhost plants of $B$. longicaudatus (Perry and Rhoades, 1982; Robbins and Barker, 1973; Smart and Nguyen, 1991). This California sting nematode population appeared to be most similar in its host preference to populations from Georgia and perhaps Florida (Abu-Gharbieh and Perry, 1970; Dickson, personal communication), but clearly differed from a North Carolina population (Robbins and Barker, 1973).

The capability of the nematode population to multiply rapidly and to parasitize Elymus smithii (Rybd.) Gould, C. dactylon, Gossypium hirsutum L., S. melongena, Lactuca sativa L., Allium cepa L., and Sporobolus indicus (L.) R. $\mathrm{Br}$. at an early plant vegetative stage resulted in a strong and significant reduction in root weight compared with plants grown in sting nematode-free soil $(P \leq 0.05$, data not shown). Smart and Nguyen (1991) reported that as little as three sting nematodes per $100 \mathrm{~g}$ of soil could result in significant yield loss in a field production situation. The absence of a significant root weight reduction for other good hosts might have resulted from their capacity to compensate for the nematode damage. Tolerance to the sting nematode in some grasses was observed previously in field and greenhouse trials (Boyd and Perry, 1969; Giblin-Davis et al., 1992). Moreover, root weight was not reduced in any of the plants categorized as poor or nonhosts.

Cherry et al. (1997) hypothesized that the California sting nematode population was introduced from the eastern United States. In Caribbean countries, infestations with sting nematodes are typically restricted to commercial golf courses. Most of the sod was imported from commercial producers in the southeastern United States. Similarly, in California the current known distribution of the sting nematode is restricted to a few golf courses in the Coachella Valley. However, our data demonstrated that its wide host range is not restricted to horticultural grasses or agricultural crops. Many weeds, such as Euphorbia glyptosperma Engelm., Sisymbrium irio L., Paspalum dilatatum Poir., Portulaca oleracea L., Sorghum sudanense Staph., and Cyperus esculentus L., can serve as hosts for $B$. longicaudatus. In sandy irrigated soils of the southwestern United States, this nematode constitutes a major threat to most plant industries.

\section{Literature Cited}

Abu-Gharbieh, W.I. and V.G. Perry. 1970. Host differences among Florida isolates of Belonolaimus longicaudatus Rau. J. Nematol. 2:209216.

Boyd, F.T. and V.G. Perry. 1969. The effect of sting nematodes on establishment, yield and growth of forage grasses on Florida sandy soils. Soil and Crop Sci. Soc. Florida 29:288-300.

Cherry, T., A.L. Szalanski, T.C. Todd, and T.O. Powers. 1997. The internal transcribed spacer region of Belonolaimus (Nemata: Belonolaimidae). J. Nematol. 29:23-29.

Duncan, L.W., J.W. Noling, R.N. Inserra, and D. Dunn. 1996. Spatial patterns of Belonolaimus spp. among and within citrus orchards on
Florida's central ridge. J. Nematol. 28:352-359. Esser, R.P. 1976. Sting nematodes, devastating parasites of Florida crops. Florida Dept. of Agr. and Consumer Serv., Div. Plant Ind. Nematol. Circ.18. Gainesville.

Giblin-Davis, R.M., J.L. Cisar, F.G. Biltz, and K.E. Williams. 1992. Host status of different bermudagrasses (Cynodon spp.) for the sting nematode, Belonolaimus longicaudatus. J. Nematol. 24:749-756.

Graham, T.W. and Q.L. Holdmen. 1953. The sting nematode Belonolaimus gracilis Steiner: A parasite on cotton and other crops in South Carolina. Phytopathology 43:434-439.

Jenkins, W.R. 1964. A rapid centrifugal-flotation technique for separating nematodes from soil. Plant Dis. Rptr. 48:692.

Mundo-Ocampo, M.J., J.O. Becker, and J. Baldwin. 1994. Occurrence of Belonolaimus longicaudatus on bermudagrass in the Coachella Valley. Plant Dis. 78:529.

Perry, V.G. and H.L. Rhoades. 1982. The genus Belonolaimus, p. 144-149. In: R.D. Riggs (ed.). Nematology in southern region of United States. Southern Coop. Ser. Bul. 276. Univ. Arkansas Agr. Publ., Fayetteville.

Rau, G.J. 1958. A new species of sting nematode. Proc. Helm. Soc. Washington 25:95-98.

Robbins, R.T. and K.R. Barker. 1973. Comparisons of host range and reproduction among isolates of Belonolaimus longicaudatus from North Carolina and Georgia. Plant Dis. Rptr. 57:750-754.

Robbins, R.T. and K.R. Barker. 1974. The effect of soil type, particle size, temperature, and moisture on reproduction of Belonolaimus longicaudatus. J. Nematol. 6:1-6.

Seinhorst, J.W. 1967. The relationship between population increase and population density in plant parasitic nematodes. Nematologica 13:459-442.

Smart, G.C. and K.B. Nguyen. 1991. Sting and awl nematodes: Belonolaimus spp. and Dolichodorus spp., p. 627-667. In: W.R. Nickel (ed.). Manual of agricultural nematology. Marcel Dekker, New York.

Todd, T.C. 1989. Isolate dynamics and damage potential of Belonolaimus sp. on corn. Suppl. J. Nematol. 21:697-702. 